\title{
The effect of milk fat substitution on the rheological properties of Edam-type cheese
}

\author{
Ryszard Myhan ${ }^{1} \cdot$ Tomasz Jeliński $^{2} \cdot$ Ireneusz Białobrzewski $^{1} \cdot$ Jadwiga Sadowska ${ }^{2} \cdot$ Ewelina Jachimczyk $^{1}$ (I)
}

Received: 19 February 2020 / Revised: 28 July 2020 / Accepted: 10 August 2020 / Published online: 28 August 2020

(c) The Author(s) 2020

\begin{abstract}
In cheese-like products, milk components (in particular fat) are partially or completely replaced with non-dairy substitutes. An attempt was made in this study to determine whether Edam-type cheese can be distinguished from its substitute, where milk fat was replaced with palm oil, based on rheological properties. The rheological properties of Edam cheese and its substitute were analyzed during a 16-week ripening period, based on the results of a stress-relaxation test. The values of the rheological parameters were estimated with the use of the generalized Maxwell model and a non-linear model proposed by the authors, which accounted for the plastic deformation of the analyzed samples. The study revealed that both methods were equally effective in describing the stress relaxation process; therefore, they can be regarded as equivalent. Excluding the initial stage of ripening (which is not important from the consumers' point of view), the replacement of milk fat with palm oil did not influence the rheological properties of Edam-type cheese and the cheese-like product. In subsequent stages of ripening, no significant differences were found in the rheological properties of both products, which could only be used to evaluate their ripeness.
\end{abstract}

Keywords Edam-type cheese $\cdot$ Cheese substitute $\cdot$ Cheese ripening $\cdot$ Rheological properties

$\begin{array}{ll}\text { Abbreviations } \\ \mathrm{E} & \text { Apparent elasticity }(\mathrm{Pa}) \\ \mathrm{n} & \text { Flow index } \\ \mathrm{t} & \text { Time (s) } \\ \mathrm{T}_{\text {rel }} & \text { Relaxation time (s) } \\ \varepsilon & \text { Relative strain } \\ \eta & \text { Apparent viscosity (Pa s) } \\ \kappa & \left.\text { Consistency index (Pa s }{ }^{\mathrm{n}}\right) \\ \sigma & \text { External load }(\mathrm{Pa}) \\ \sigma_{\mathrm{E}} & \text { Elastic stress }(\mathrm{Pa}) \\ \sigma_{\mathrm{N}} & \text { Viscous stress }(\mathrm{Pa}) \\ \sigma_{\mathrm{V}} & \text { Plastic deformation }(\mathrm{Pa})\end{array}$

Ewelina Jachimczyk

ewelina.jachimczyk@uwm.edu.pl

1 Faculty of Technical Sciences, University of Warmia and Mazury in Olsztyn, ul. Oczapowskiego 2, 10-719 Olsztyn, Poland

2 Division of Food Science, Institute of Animal Reproduction and Food Research, Polish Academy of Sciences, Tuwima 10, 10-748 Olsztyn, Poland

\section{Introduction}

The growing competition on the market of processed foods, including dairy products, has increased the supply of foods where selected natural ingredients are replaced with substitutes. Such products are introduced to meet consumer demand for innovative foods with altered dietary properties [1] and to decrease production costs [2-4]. The costs associated with the production of ripened cheese are most frequently reduced by substituting milk fat with vegetable oil and shortening the ripening time [5].

Various sensory and instrumental methods are deployed to identify the properties of food products [6-15]. According to the literature, textural and rheological properties, which are often correlated with the chemical composition of foods, support rapid and low-cost identification of products and evaluations of food quality in industrial applications [16, 17]. Adulteration in dairy products (e.g., with vegetable oil) can be detected with the use of various instrumental methods, including chromatographic, immunological, physical, and mechanical techniques [5]. Spectroscopic techniques have also been applied to determine cheese quality and authenticity [18] and to discriminate Emmental cheeses belonging to different brand products [19]. The textural 
properties of cheese where milk fat was substituted in whole or in part with vegetable oil were investigated by $\mathrm{Yu}$ and Hammond [20], Lobato-Calleros et al. [21], Cunha et al. [22], Arslan et al. [23], Abd El-Salam [24], Al-Ismail et al. [25], Felfoul et al. [26], Hjalmarsson [27], Badem and Uçar [28], Yagoub et al. [29] and Abd El-Wahed and Hassanien [30]. The rheological properties of cheese were discussed by Lee et al. [31], Budiman et al. [32], Liu et al. [33], Sadowska et al. [34], Oliveira et al. [35], Sołowiej [36], Cunha et al. [37], Farbod et al. [38], Hanáková et al. [39], Karaman et al. [40], Henno et al. [41], Rafiq and Ghosh [42], and Giri et al. [43]. Changes in the viscoelastic properties of cheese were also evaluated during ripening. In semi-hard, ripened rennetcoagulated cheese, such changes were examined in Gouda [44, 45], Cheddar [46, 47], Monterey Jack [48] and Edam cheese [49]. The rheological properties of low-fat (17\% fat) and high-fat (27\% fat) Edam cheese were analyzed.

The rheological properties of cheese are determined in compression tests $[8,10,13,27,33,38,42,44,46]$, stress relaxation tests $[13,33,40,44,50-52]$ and creep tests $[1,6$, 7]. Rheological parameters are usually estimated based on the generalized Maxwell model [13, 32, 34, 40, 50-53] and the Kelvin-Voigt model [54-57], but the Herschel-Bulkley model [1, 58-60], Burgers model [40, 61, 62] and Peleg's empirical model [40, 52, 63, 64] are also applied. According to the above models, the deformed sample returns to its original state after a given period of time, once the stress/load is removed. However, cheese (and other biological materials) exhibit permanent plastic deformation. Therefore, the model that accounts for this type of deformation was used in the present study.

Although cheese-like products have been relatively well researched, still little is known about potential differences in the rheological properties and ripening of Dutch-type cheeses and their substitutes where milk was completely replaced with palm oil. To fill this knowledge gap, the present study was designed to determine whether cheese ripeness and the type of fat applied in the production process can be determined based solely on the rheological properties of Edam-type cheese and its substitute.

\section{Materials and methods}

\section{Materials}

The study was performed on commercially available blocks of full-fat Edam-type cheese (Edam) and a cheese substitute (Substitute) where milk fat was substituted in its entirety with palm oil. Both products were purchased from the same dairy plant in north-eastern Poland. Both Edam-type cheese and the cheese substitute were produced in the same season (winter), on the same day, from the same milk batch, and with the use of the same equipment and technology.

After production and ripening, cheese and cheese substitute samples were transported to a laboratory and stored in a refrigerating unit at the same temperature $\left(8^{\circ} \mathrm{C}\right)$. Before the rheological analysis, the cheese was tempered at $20{ }^{\circ} \mathrm{C}$ for $20 \mathrm{~min}$. During this time and during the test, the samples were stored in ziplock kitchen plastic bags. Two cheese blocks were analyzed at each stage of the analysis.

\section{Chemical analysis}

Water content was determined by dehydration at $105^{\circ} \mathrm{C}$ for $4 \mathrm{~h}$ in the SML 32/250 drying oven (Zalmed, Poland) according to AOAC [65] method No 926.08. Total fat content (TF) was determined according to AOAC method No 933.30. Fat was extracted from dried samples by the Soxhlet method, with petroleum ether as the extraction solvent. The time of fat extraction was $8 \mathrm{~h}$. Total nitrogen (TN) was determined according to the micro-Kjeldahl method (AOAC No. 920.105). TCA-soluble nitrogen (TCASN) was determined according to the method proposed by Tavaria et al. [66] and was expressed as a percentage of total nitrogen. $\mathrm{pH}$ values were determined in a 1:1 mixture of grated cheese and deionized water, using the CX-501 multifunction meter (Elmetron, Poland) with an ERH-11S electrode (Hydromet, Poland). Three samples of cheese and its substitute were analyzed in each stage of ripening.

\section{Rheological analysis}

Cylindrical samples with a diameter of $10.0 \pm 0.5 \mathrm{~mm}$ were cut from cheese blocks with a cork-borer and divided into segments with a height of $5.0 \pm 0.5 \mathrm{~mm}$. Cheese samples were placed in ziplock kitchen plastic bags to prevent moisture loss, and they were kept in a thermostatic chamber $\left(18^{\circ} \mathrm{C}\right)$ for around $20 \mathrm{~min}$ before the analysis of temperature distribution within the sample. The rheological properties of the samples were determined in a relaxation test in the Instron 1011 testing machine (Juston, UK) equipped with a $50 \mathrm{~N}$ load cell with a $25 \mathrm{~mm}$ cylinder probe. Each sample was compressed at a rate of $50 \mathrm{~mm} / \mathrm{min}$ to $25 \%$ of its original height. Each test lasted $420 \mathrm{~s}$. Time-dependent changes in stress were recorded twice a second in a computer application. Stress relaxation tests were conducted on the day of production and after $2,4,7,10,13$, and 16 weeks of ripening. Each test was conducted in six replicates. 


\section{Rheological model}

The influence of fat substitution and ripening time on the rheological properties of the examined materials was determined with the use of two methods. The first method involved the generalized Maxwell model which is based on the superposition of two distinctive contributions describing the distribution of relaxation times (Method I). The second method was developed based on the laws of physics and direct analysis of test results, which supported the formulation of a rheological model (Method II).

\section{Method I}

A semi-empirical Maxwell model comprising a Hookean element and three Maxwell (Fig. 1a) elements connected in parallel was developed based on the results of previous experiments $[34,51]$ to describe the elastic and viscous properties of cheese. Assuming that only the spring is initially deformed in three Maxwell bodies, the solution for the generalized Maxwell model was described by Eq. (1):

$$
\begin{aligned}
E(t)=\frac{\sigma(t)}{\varepsilon_{0}}= & {\left[E_{0}+E_{1} \cdot \exp \left(\frac{-E_{1} \cdot t}{\eta_{1}}\right)\right.} \\
& \left.+E_{2} \cdot \exp \left(\frac{-E_{2} \cdot t}{\eta_{2}}\right)+E_{3} \cdot \exp \left(\frac{-E_{3} \cdot t}{\eta_{3}}\right)\right]
\end{aligned}
$$

It was assumed that apparent elasticity is the sum of all of modeled elastic elements and that apparent viscosity is the sum of all of modeled viscous elements.

\section{Method II}

The analyzed phenomena were described with a non-linear rheological model [67] combining the properties of an ideal Hookean elastic solid, ideal Newtonian viscous fluid, and ideal Saint-Venant plastic solid (Fig. 1b). The stresses appearing in the material were treated as a vector sum of the stresses resulting from elastic stress $\sigma_{\mathrm{H}}$, viscous stress $\sigma_{\mathrm{N}}$ and plastic deformation $\sigma_{\mathrm{V}}$ :

$\sigma(t)=\sigma_{H}+\sigma_{N}+\sigma_{V}$

The analyzed phenomena occur at constant values of relative deformation $\varepsilon(t)$, which implies the absence of changes in stress $\sigma_{(H+V)}$ resulting from the material's elasticity and plasticity:

$\varepsilon(t)=$ const $\rightarrow \sigma_{H}+\sigma_{V}=\sigma_{(H+V)}=$ const

Therefore, stress $\sigma(t)$ is caused by material flow. No significant changes in the material's density, composition or structure are observed during flow; therefore, it can be assumed that the value of the dynamic viscosity index is also constant. The above assumption implies that the material's unknown flow rate changes in a non-linear fashion. This phenomenon is generally described with Peleg's empirical model [68], but a modified version of that model produces much better results in biological materials [69]:

$\sigma(t)=\sigma_{0}\left(1-\frac{t^{n}}{k_{1}+k_{2} t^{n}}\right)$,

where: $\sigma_{0}=\sigma(t=0)=\max [\sigma(t)], n-$ flow index, $k_{1}-$ initial rate of stress relaxation, $k_{2}$-the hypothetical asymptotic value of normalized stress at the end of the stress relaxation phase.

Equation (4) can be used to determine total stress resulting from the viscoplastic properties of the examined material:

$\sigma_{(H+V)}(t)=\lim _{t \rightarrow \infty} \sigma(t)=\sigma_{0} \cdot\left(1-\frac{1}{k_{2}}\right)$,

and when Eqs. (4) and (5) are substituted into Eq. (2), the result is:

$\sigma_{N}(t)=\sigma_{0} \cdot\left(\frac{1}{k_{2}}-\frac{t^{n}}{k_{1}+k_{2} t^{n}}\right)$
Fig. 1 Rheological model: (a) Method I, (b) - Method II
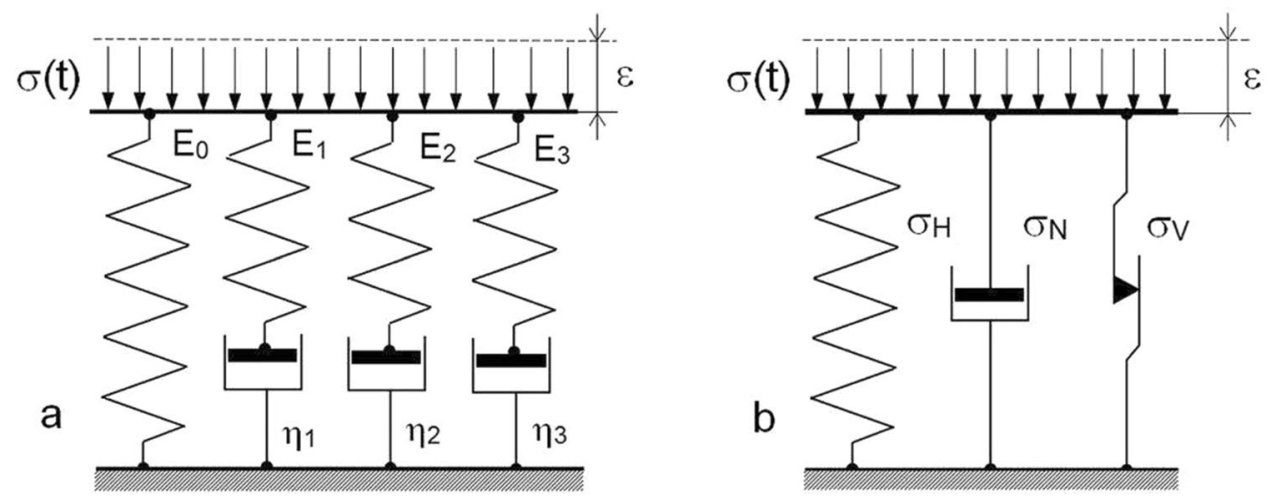
Parameters $k_{1}$ and $k_{2}$ are estimated, and stress relaxation time:

$T_{r e l}=\left(\frac{(e-1) k_{1}}{k_{2}}\right)^{\frac{1}{n}} \cong\left(\frac{1.7183 k_{1}}{k_{2}}\right)^{\frac{1}{n}}$

and the consistency index:

$\kappa=\frac{k_{1} \sigma_{0}}{k_{2}}$

which is equivalent to the power-law index in the Ostwald de Waele model, are calculated.

\section{Results and discussion}

\section{Chemical properties}

The chemical composition of the analyzed products is presented in Table 1. Water, fat, and total nitrogen content remained fairly constant between the beginning and the end of the period considered. Chemical compounds are transformed during ripening (proteolysis and lipolysis), which induces clear changes in structure, texture, and sensory attributes. Proteolysis leads to a steady increase in peptide concentration, an important indicator of cheese ripeness [70]. The observed increase in peptide concentration (expressed by TCA-soluble nitrogen) in all samples was indicative of normal ripening, but the ripening of the cheeselike product (Substitute) proceeded at a slower rate. After ripening, the $\mathrm{pH}$ of both products was somewhat higher, which suggests that the analyzed samples had adequately ripened [71-73].

\section{Rheological properties}

The unknown values of the parameters in Eqs. (1) and (4) were estimated by the least-squares method with the use of the Levenberg-Marquardt algorithm in the Statistica v. 12 program (StatSoft, USA). In each case, calculations were performed at a significance level of $p=0.05$ and a sample size of $s=5046$. A preliminary analysis of the parameters in Eq. (4) revealed that the flow index remained constant at $n \cong 0.47 \pm 0.01$ in all cases; therefore, only the remaining parameters in Eq. (4) were estimated in successive steps. The adopted research methods were used to determine the following rheological properties: apparent elasticity $E$, apparent viscosity $\eta$ [Eq. (1)], stress relaxation time $T_{r e l}$ [Eq. (7)] and consistency index $\kappa$ [Eq. (8)].

The uncertainty of measurement of rheological parameters was determined by calculating the total derivative, i.e., by summing up the products of partial derivatives [Eq. (1), (7) and (8)], and the standard error of the estimate of the parameters in Eqs. (1) and (4). The results of the simulations conducted with both methods were compared with the results of the measurements involving the root mean square (RMS) calculated with the following formula:

$R M S=\sqrt{\frac{\sum_{i=1}^{n}\left(\operatorname{Exp}_{i}-\operatorname{Mod}_{i}\right)^{2}}{\sum_{i=1}^{n} \operatorname{Exp}_{i}^{2}}}$

The results are presented in Table 2 and Fig. 2. Both methods were equally effective in describing the stress relaxation process; therefore, they can be regarded as equivalent. The above was confirmed by partial simulations as well as RMS values relating to the entire ripening process.

The rheological properties of both products varied significantly until the fourth week of ripening (excluding the relaxation time). The fourth week of ripening was a characteristic period during which the values of all estimated parameters in both models were significantly higher in the samples where milk fat was replaced with palm oil. In subsequent stages of ripening, no significant differences were found in the rheological properties of both products. A similar trend was observed in Cheddar cheese [47] and Edam-type cheese [41], where more pronounced changes in
Table 1 Proximate chemical composition (average value \pm standard deviation) and changes in ripening indices

\begin{tabular}{|c|c|c|c|c|c|}
\hline \multirow[t]{2}{*}{ Parameter } & & \multicolumn{2}{|c|}{ Edam-type cheese } & \multicolumn{2}{|l|}{ Substitute } \\
\hline & & Week 0 & Week 16 & Week 0 & Week 16 \\
\hline Water & {$[\%]$} & $40.9 \pm 0.70$ & $41.7 \pm 0.81$ & $41.2 \pm 0.77$ & $39.8 \pm 0.91$ \\
\hline Total fat & {$[\% \mathrm{DM}]$} & $43.1 \pm 1.49$ & $44.8 \pm 0.72$ & $47.3 \pm 3.27$ & $47.8 \pm 1.71$ \\
\hline Total nitrogen & {$[\% \mathrm{DM}]$} & $6.79 \pm 0.29$ & $7.07 \pm 0.31$ & $7.18 \pm 0.31$ & $6.75 \pm 0.28$ \\
\hline TCA-soluble nitrogen & {$[\% \mathrm{Nt}]$} & $2.45 \pm 0.21$ & $9.45 \pm 0.24$ & $2.09 \pm 0.08$ & $8.20 \pm 0.18$ \\
\hline $\mathrm{pH}^{\mathrm{a}}$ & {$[-]$} & $5.45 \pm 0.03$ & $5.61 \pm 0.01$ & $5.36 \pm 0.02$ & $5.75 \pm 0.02$ \\
\hline
\end{tabular}

$D M$ dry matter

${ }^{a}$ range of values between the beginning and end of ripening 


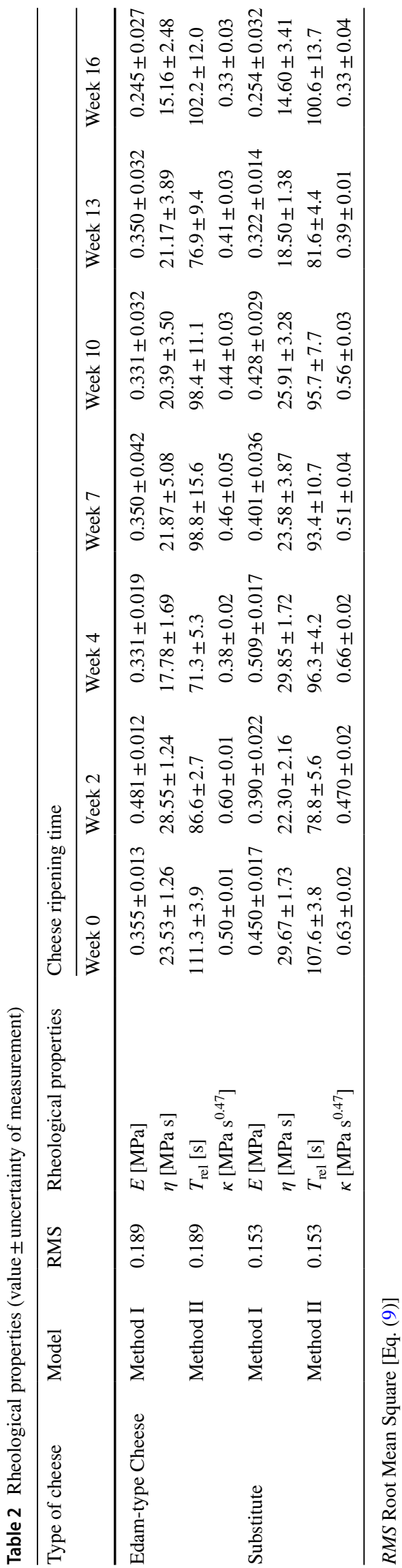

the viscoelastic properties were also noted during the first 4 weeks, and the analyzed parameters stabilized in successive weeks of ripening.

From the consumer's perspective, the differences in rheological properties observed at the beginning of the ripening process are not important since the product is not yet ready for consumption. Since both analyzed products were made with the use of the same production technology, they were analyzed together to determine whether a correlation exists between their rheological properties and ripening time. An analysis of both products revealed a gradual decrease in the values of elasticity $E$ (Fig. 3a), viscosity $\eta$ (Fig. 3b), the consistency index $\eta$ (Fig. 3c), and stress resulting from plastic deformation $\sigma_{\mathrm{V}}$ (Fig. 3d) in successive weeks of ripening. However, in the overall stress balance (Eq. (5)), the ratio of elastic stress to the stress resulting from the plastic deformation of the analyzed material remained constant throughout the entire ripening period, at approximately $67 \%$.

\section{Conclusions}

The values of RMS indicate that both research methods were equally effective in describing the stress relaxation process, and therefore they can be regarded as equivalent. However, the proposed non-linear model (method II) accounts also for the permanent plastic deformation of Edam-type cheese and its substitute, and the estimated value of the flow index is close to that determined for highly-processed meat products [67], thus indicating that the viscous properties of both analyzed products may correspond to the behavior of a nonNewtonian shear thinning fluid [74, 75].

The rheological properties of Edam-type cheese and its substitute differed significantly only in the initial stage of ripening (until week 4). The fourth week of ripening was a characteristic period during which the values of all estimated parameters in both models were considerably higher in the samples where milk fat was replaced with palm oil. However, in successive weeks of ripening, the replacement of milk fat with vegetable oil had no significant influence on the rheological properties of cheese and the cheese-like product, which were indistinguishable in this respect. After the above period, rheological properties can only be used to evaluate ripeness because in subsequent stages of ripening, a gradual decrease is observed in the values of apparent elasticity and apparent viscosity (method I), and the consistency index and stress resulting from plastic deformation (method II). 
a

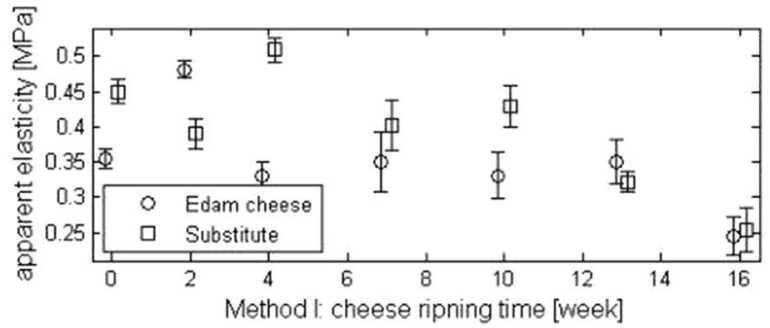

c

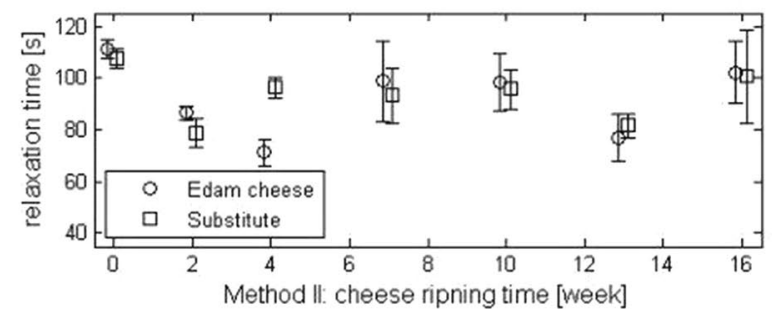

b

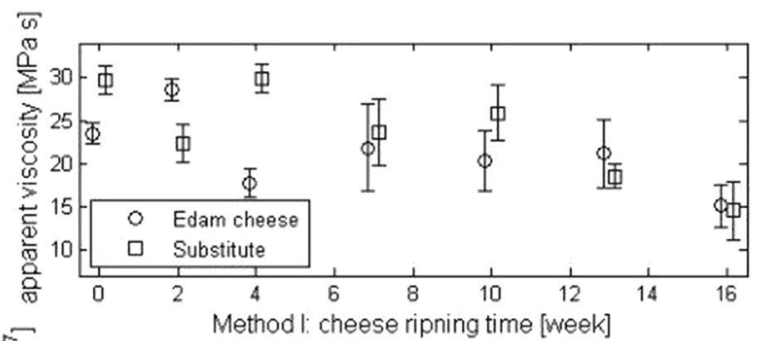

d

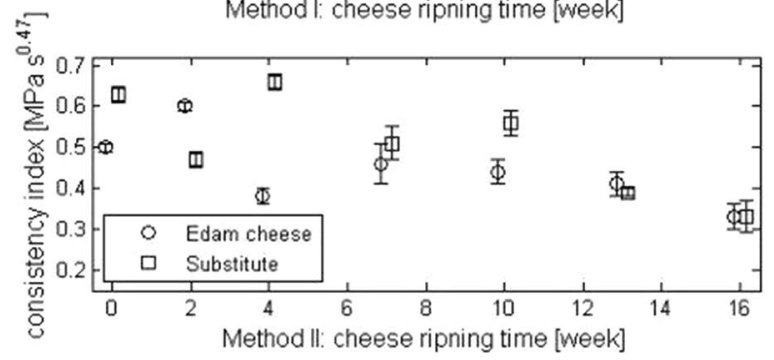

Fig. 2 Rheological properties: (a) - apparent elasticity, (b) - apparent viscosity, (c) - relaxation time, (d) - consistency index
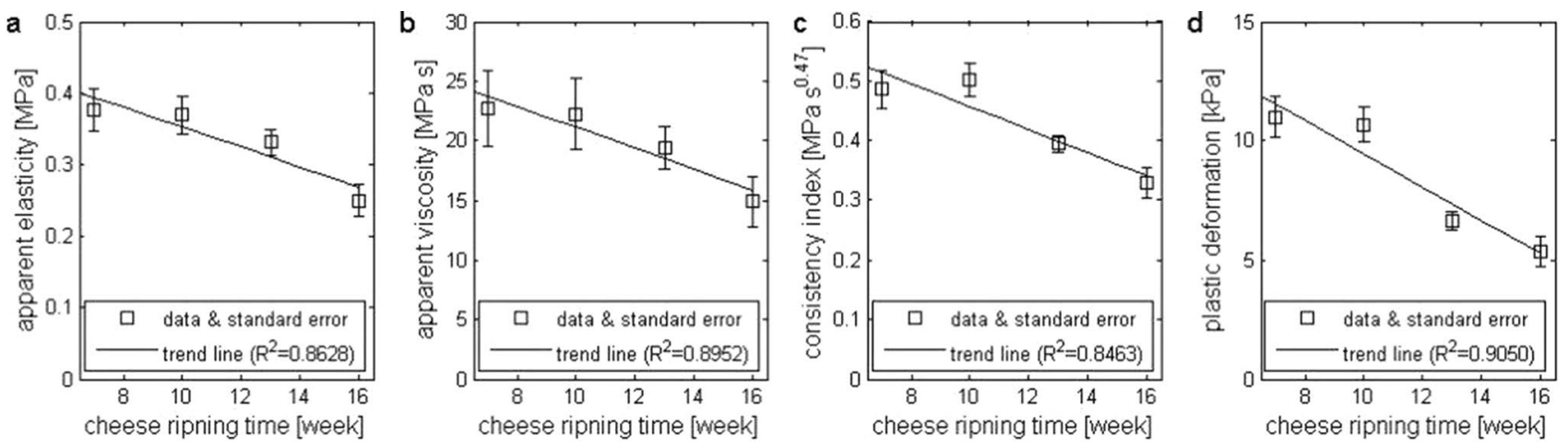

Fig. 3 Rheological properties (trend lines): (a) - apparent elasticity, (b) - apparent viscosity, (c) - consistency index, (d) - plastic deformation

\section{Compliance with ethical standards}

Conflict of interest All authors declare that they have no known competing financial interests or personal relationships that could have appeared to influence the work reported in this paper.

Compliance with ethics requirements This article does not contain any studies with human or animal subjects.

Open Access This article is licensed under a Creative Commons Attribution 4.0 International License, which permits use, sharing, adaptation, distribution and reproduction in any medium or format, as long as you give appropriate credit to the original author(s) and the source, provide a link to the Creative Commons licence, and indicate if changes were made. The images or other third party material in this article are included in the article's Creative Commons licence, unless indicated otherwise in a credit line to the material. If material is not included in the article's Creative Commons licence and your intended use is not permitted by statutory regulation or exceeds the permitted use, you will need to obtain permission directly from the copyright holder. To view a copy of this licence, visit http://creativecommons.org/licenses/by/4.0/.

\section{References}

1. Ma Z, Boye JI (2013) Advances in the design and production of reduced-fat and reduced-cholesterol salad dressing and mayonnaise: a review. Food Bioprocess Technol 6(3):648-670

2. Bachmann H-P (2001) Cheese analogues: a review. Int Dairy J 11:505-515

3. Chavan RS, Jana A (2007) Cheese substitutes: an alternative to natural cheese - a review. Int J Food Sci Technol Nutr 2(2):25-39

4. Sales DC, Rangel AHN, Urbano SA, Borges KC, Andrade Neto JC, Chagas BME (2016) Cheese yield in Brazil: state of the art. Food Sci Technol 36(4):563-569

5. Banach JK, Żywica R (2012) An attempt to use the electrical conductivity of ripening cheeses for the evaluation of their adulteration with vegetable oils. Zarządzanie i Finanse 3(2):237-250 (in Polish)

6. Drake MA, Gerard PD, Truong VD, Daubert CR (1999) Relationship between instrumental and sensory measurements of cheese texture. J Texture Stud 30(4):451-476

7. Foegeding EA, Brown J, Drake MA, Daubert CR (2003) Sensory and mechanical aspects of cheese texture. Int Dairy J 13:585-591 
8. Kapoor R, Metzger LE (2008) Process cheese: scientific and technological aspects - a review. Compr Rev Food Sci Food Saf 7(2):194-214

9. Ribeiro APB, Basso RC, Grimaldi R, Gioielli LA, Gonçalves LAG (2009) Instrumental Methods for the Evaluation of Interesterified Fats. Food Anal Methods 2(4):282-302

10. Aday MS, Caner C, Yuceer YK (2010) Instrumental and sensory measurements of Ezine cheese texture. Akademik Gida 8(3):6-10

11. Subramanian A, Rodriguez-Saona L (2010) Chemical and instrumental approaches to cheese analysis. Adv Food Nutr Res 59:167-213

12. Silva RCSN, Minim VPR, Vidigal MCRT, Silva AN, Simiqueli AA, Minim LA (2012) Sensory and instrumental consistency of processed cheeses. J Food Res 1(3):204-213

13. Chen L, Opara UL (2013) Texture measurement approaches in fresh and processed foods - a review. Food Res Int 51(2):823-835

14. Ntakatsane MP, Liu XM, Zhou P (2013) Short communication: Rapid detection of milk fat adulteration with vegetable oil by fluorescence spectroscopy. J Dairy Sci 96(4):2130-2136

15. Kim H-J, Park J-M, Lee J-H, Kim J-M (2016) Detection for nonmilk fat in dairy product by gas chromatography. Korean J Food Sci Anim Resour 36(2):206-214

16. Hort J, Le Grys G, Woodman J (1997) The relationships between the chemical, rheological and textural properties of Cheddar cheese. Le Lait INRA Editions 77(5):587-600

17. Myhan R, Markowski M, Daszkiewicz T, Korpusik A, Zapotoczny P (2016) Identification of the chemical composition of meat products based on their rheological properties. J Texture Stud 47(6):504-551

18. Woodcock T, Fagan CC, O'Donnell CP, Downey G (2008) Application of near and mid-infrared spectroscopy to determine cheese quality and authenticity. Food Bioprocess Technol 1(2):117-129

19. Botosoa EP, Karoui R (2013) Characterisation of emmental cheeses within different brand products by combining infrared and fluorescence spectroscopies. Food Bioprocess Technol 6(9):2365-2375

20. Yu L, Hammond EG (2000) Production and characterization of a swiss cheese-like product from modified vegetable oils. J Am Oil Chem Soc 77(9):917-924

21. Lobato-Calleros C, Reyes-Hernández J, Beristain CI, HornelasUribe Y, Sánchez-García JE, Vernon-Carter EJ (2007) Microstructure and texture of white fresh cheese made with canola oil and whey protein concentrate in partial or total replacement of milk fat. Food Res Int 40(4):529-537

22. Cunha CR, Dias AI, Viotto WH (2010) Microstructure, texture, colour and sensory evaluation of a spreadable processed cheese analogue made with vegetable fat. Food Res Int 43(3):723-729

23. Arslan S, Topcu A, Saldamli I, Koksal G (2014) Use of corn oil in the production of Turkish white cheese. J Food Sci Technol 51(10):2382-2392

24. Abd El-Salam BA (2015) Effect of milk fat replacement with vegetable oil and/or whey protein concentrate on microstructure, texture and sensory characteristics of fresh soft cheese. J Anim Feed Sci 10(3):117-125

25. Al-Ismail K, Al-Hiary B, Al-Dabbas M (2015) Evaluation of some chemical and sensory properties of processed cheese analogue with selected vegetable oils. Int J Chem Process Eng 2(6):75-85

26. Felfoul I, Bornaz S, Baccouche A, Sahli A, Attia H (2015) Lowfat Gouda cheese made from bovine milk-olive oil emulsion: physicochemical and sensory attributes. J Food Sci Technol 52(10):6749-6755

27. Hjalmarsson M (2015) The effect of vegetable fat on cheese yield and cheese properties Publikation/Sveriges lantbruksuniversitet. Institutionen för livsmedelsvetenskap, Uppsala
28. Badem A, Uçar G (2016) Cheese Analogues. J Food Dairy Technol 4(3):44-48

29. Yagoub AH, Abdel-Razig KA, Abdalla MI (2016) Effect of different levels of palm oil on the compositional quality of Mozzarella cheese during storage. Am J Res Commun 4(4):97-112

30. Abd El-Wahed EM, Hassanien MFR (2019) Chemical, rheological and sensory characteristics of processed cheese spread analogues. Carpathian J Food Sci Technol 11(1):135-148

31. Lee SK, Anema S, Klostermeyer H (2004) The influence of moisture content on the rheological properties of processed cheese spreads. Int J Food Sci Technol 39:763-771

32. Budiman M, Stroshine RL, Campanella OH (2000) Stress relaxation and low field proton magnetic resonance studies of cheese analog. J Texture Stud 31(5):477-498

33. Liu H, Xu XM, Guo SD (2008) Comparison of full-fat and low-fat cheese analogues with or without pectin gel through microstructure, texture, rheology, thermal and sensory analysis. Int J Food Sci Technol 43:1581-1592

34. Sadowska J, Białobrzewski I, Jeliński T, Markowski M (2009) Effect of fat content and storage time on the rheological properties of Dutch-type cheese. J Food Eng 94(3-4):254-259

35. Oliveira NM, Dourado FQ, Peres AM, Silva MV, Maia JM, Teixeira JA (2011) Food Bioprocess Technol 4(8):1414-1421

36. Sołowiej B (2012) Textural, rheological and melting properties of acid casein reduced-fat processed cheese analogues. Milchwissenschaft 67(1):9-13

37. Cunha CR, Grimaldi R, Alcântara MR, Viotto WH (2013) Effect of the type of fat on rheology, functional properties and sensory acceptance of spreadable cheese analogue. Int J Dairy Technol 66(1):54-62

38. Farbod F, Kalbasi A, Moini S, Emam-Djomeh Z, Razavi H, Mortazavi A, Beheshti H-R (2013) The effects of storage time on physiochemical, rheological, micro-structural and sensory properties of feta cheese fortified with fish and olive oils. J Nutr Food Sci 3(5):1-8

39. Hanáková Z, Buňka F, Pavlínek V, Hudečková L, Janiš R (2013) The effect of selected hydrocolloids on the rheological properties of processed cheese analogues made with vegetable fats during the cooling phase. Int J Dairy Technol 66(4):484-489

40. Karaman S, Yilmaz MT, Toker OS, Dogan M (2016) Stress relaxation/creep compliance behaviour of kashar cheese: scanning electron microscopy observations. Int J Dairy Technol 69(2):254-261

41. Henno M, Jõudu I, Kaart T, Veskioja A, Ots M (2017) Changes in rheological properties of Edam-type cheese during ripening. Agric Food Sci 26(4):198-206

42. Rafiq SM, Ghosh BC (2017) Effect of peanut addition on the fatty acid profile and rheological properties of processed cheese. J Food Process Technol 8(8):690

43. Giri SK, Tripathi MK, Kotwaliwale N (2018) Effect of composition and storage time on some physico-chemical and rheological properties of probiotic soy-cheese spread. J Food Sci Technol 55(5):1667-1674

44. Bertola NC, Califano AN, Bevilacqua AE, Zaritzky NE (2000) Effects of ripening conditions on the texture of Gouda cheese. Int J Food Sci Technol 35(2):207-214

45. Taivosalo A, Kriščiunaite T, Stulova I, Part N, Rosend J, Sõrmus A, Vilu R (2019) Ripening of hard cheese produced from milk concentrated by reverse Osmosis. Foods 8(5):1-19

46. Hort J, Le Grys G (2001) Developments in the textural and rheological properties of UK Cheddar cheese during ripening. Int Dairy J 11(4-7):475-481

47. Brickley CA, Auty MAE, Piraino P, McSweeney PLH (2007) The effect of natural cheddar cheese ripening on the functional and textural properties of the processed cheese manufactured therefrom. J Food Sci 72(9):483-490 
48. Van Hekken DL, Tunick MH, Park YW (2004) Rheological and proteolytic properties of monterey jack goat's milk cheese during aging. J Agric Food Chem 52(17):5372-5377

49. Küçüköner E, Haque ZU (2003) Physico-chemical and rheological properties of full fat and low fat edam cheeses. Eur Food Res Technol 217(4):281-286

50. Subramanian R, Muthukumarappan K, Gunasekaran S (2006) Linear viscoelastic properties of regular- and reduced-fat pasteurized process cheese during heating and cooling. Int J Food Prop 9(3):377-393

51. Del Nobile MA, Chillo S, Mentana A, Baiano A (2007) Use of the generalized Maxwell model for describing the stress relaxation behavior of solid-like foods. J Food Eng 78(3):978-983

52. Abu-Waar Z, Saleh M, Lee YS (2013) Viscoelastic and textural properties of cheddar cheese under various temperature conditions. Life Sci J 10(3):2126-2131

53. Kim J-Y, Lee K-B, Shin Y-K, Baik M-Y, Kim B-Y (2015) Changes in the rheological properties of cheddar cheese at different storage temperatures. Food Sci Biotechnol 24(4):1349-1353

54. Subramanian R, Muthukumarappan K, Gunasekaran S (2003) Effect of methocel as a water binder on the linear viscoelastic properties of mozzarella cheese during early stages of maturation. J Texture Stud 34:361-380

55. Faber TJ (2015) Engineering cheese sensory texture: using structure-property modeling. Technische Universiteit Eindhoven, Eindhoven

56. Banks HT, Hu S, Kenz ZR (2011) A brief review of elasticity and viscoelasticity for solids. Adv Appl Math Mech 3(1):1-51

57. Pritchard RH, Terentjev EM (2017) Oscillations and damping in the fractional Maxwell materials. J Rheol 61(2):187-203

58. Gallegos C, Franco JM, Partal P (2004) Rheology of Food Dispersions. Rheol Rev 4:19-65

59. Limanowski J (2016) Changes in cream cheese rheological properties during mixing with a fruit concentrate. Pol J Nat Sci 31(2):231-238

60. Bertsch P, Savorani L, Fischer P (2019) Rheology of Swiss cheese fondue. ACS Omega 4(1):1103-1109

61. Kuo M-I, Wang Y-C, Gunasekaran S (2000) A viscoelasticity index for cheese meltability evaluation. J Dairy Sci 83(3):412-417

62. O'Callaghan DJ, Guinee TP (2004) Rheology and texture of cheese. In: Fox PF, McSweeney PLH, Cogan TM, Guinee TP (eds) Cheese: Chemistry, Physics and Microbiology, vol 1. Elsevier Academic Press, Amsterdam, pp 511-540

63. Venugopal V, Muthukumarappan K (2001) Stress relaxation characteristics of Cheddar cheese. Int J Food Prop 4(3):469-484
64. Joshi NS, Jhala RP, Muthukumarappan K, Acharya MR, Mistry VV (2004) Textural and rheological properties of processed cheese. Int J Food Prop 7(3):519-530

65. AOAC (1990) Association of Official Analytical Chemists. Official method of analysis of the Association of Official Analytical Chemists, Washington DC

66. Tavaria FK, Franco I, Carballo FJ, Malcata FX (2003) Amino acid and soluble nitrogen evolution throughout ripening of Serra da Estrela cheese. Int Dairy J 13(7):537-545

67. Myhan R, Białobrzewski I, Markowski M (2012) An approach to modeling the rheological properties of food materials. J Food Eng 111(2):351-359

68. Peleg M (1980) Linearization of relaxation and creep curves of solid biological materials. J Rheol 24(4):451-463

69. Myhan R, Markowski M, Daszkiewicz T, Zapotoczny P, Sadowski P (2015) Non-linear stress relaxation model as a tool for evaluating the viscoelastic properties of meat products. J Food Eng 146:107-115

70. Coker CJ, Crawford RA, Johnston KA, Singh H, Creamer LK (2005) Towards the classification of cheese variety and maturity on the basis of statistical analysis of proteolysis data - a review. Int Dairy J 15(6-9):631-643

71. McSweeney PLH, Hayaloglu AA, O'Mahony JA, Bansal N (2006) Perspectives on cheese ripening. Aust J Dairy Technol 61(2):69-77

72. Pytel R, Kumbar V, Kilian L, Sustova K (2016) Influence of ripening on the physicochemical and sensory profile of semi-hard cheese. MendelNet 23:622-627

73. Gigante ML, Almena-Aliste M, Kindstedt PS (2006) Effect of cheese $\mathrm{pH}$ and temperature on serum phase characteristics of cream cheese during storage. J Food Sci 71(1):7-11

74. Chattong U, Apichartsrangkoon A, Bell AE (2007) Effects of hydrocolloid addition and high pressure processing on the rheological properties and microstructure of a commercial ostrich meat product "Yor" (Thai sausage). Meat Sci 76(3):548-554

75. Takahiko S, Takamasa K, Akiko H (2005) Analysis of creep test on gel-type processed food, mainly Sausage. J Jpn Soc Food Sci 52(11):517-521

Publisher's Note Springer Nature remains neutral with regard to jurisdictional claims in published maps and institutional affiliations. 